\title{
Financial Literacy \\ Self-Evaluation of Young People in Latvia
}

Financial Literacy Self-

Evaluation of Young

People in Latvia

Submitted 02/2021

Accepted for

publication 06/2021

\author{
Evija Dundure \\ University of Latvia \\ Biruta Sloka \\ University of Latvia \\ Гrossef http://dx.doi.org/10.5755/j01.eis.1.15.28902
}

\section{Abstract}

Introduction

\section{ktu}

European Integration Studies No. 15 / 2021, pp. 160-169 doi.org/10.5755/j01.eis.1.15.28902
Regular and proportionate voluntary savings in private pension funds can become an important part of oldage pensions. However, this can happen if the savings are made for a long period of time. This justifies the target group of the 3rd pension level, which are young people who have started to receive a regular income from their professional activity.

One of the most discussed issues in promoting voluntary pension savings is the level of financial literacy. In addition to other motivating factors, such as financial incentives, the level of knowledge of the population about the opportunities to participate in the third pillar of pensions makes them want to build up voluntary savings. Effective communication of information to a precise target audience is one of the main tasks of government agencies in formulating pension policy.

In order to assess the impact of various socio-economic factors on young people's knowledge of savings for pension formation, a survey of Latvian youth was conducted in February-March 2021, addressing youth organizations and universities. The survey is designed using closed and semi-closed questions, in several questions respondents were asked to provide ratings using the Likert scale.

The survey provides answers to the question about the level of knowledge of Latvian youth about the current pension system, emphasizing the investor's right to handle investments in private pension funds, as well as the basic conditions for creating savings at the $2 \mathrm{nd}$ and $3 \mathrm{rd}$ pension levels. The task of the study was to analyze the respondents' financial literacy self-evaluation answers based on the main socio-economic factors - gender, age and income. The results of the study confirm that the level of financial literacy of young people differs according to age, gender and income level.

KEYWORDS: Pensions, Voluntary savings, Financial literacy, Young People, Social security.

The importance of voluntary pension savings in pension funds is growing in Latvia and in the world. Based on the profitability aspect of long-term savings, it is important to accumulate as early as possible and to create preconditions for greater involvement of young people in pension planning and savings. Publicly available information, as well as scientific research, shows that it is young people who are least involved in voluntary pension accumulation. In most of developed countries' pension policies are based on three pillars, so the issue of young people's readiness to think about and plan for pension savings at an early age is a priority. One of the most discussed issues among academics in promoting voluntary pension savings is the level of financial literacy. Financial literacy is the basis for government-designed support mechanisms, including financial incentives, to deliver results and people's level of knowledge to participate in the third pillar of pensions and to build up voluntary savings. 
However, the desire of pension policy makers to involve the population in the formation of pension savings and to shift the investment risk to people's responsibility poses certain challenges. It is difficult for people, especially younger ones, to make long-term decisions such as the desired amount of pension and the amounts that must be postponed today in order to create it (Kotecha, Kinsella \&Arthur, 2010). Attempts are being made to raise the level of financial literacy for people to choose in favor of voluntary savings (Strauss, 2008). In addition, it is important to note that while widely available information can improve financial literacy, there are behavioral barriers, including short-sightedness, cynicism and inertia, that hinder the accumulation of assets today (Wicks, Horack, 2009).

Since 2014, Latvia has implemented a strategy for promoting the financial literacy of the population (www.finansupratiba.lv), which highlights the importance of the aspect of financial literacy of young people in reviving the tradition of financial planning and savings. The tasks defined in it include the improvement of the state education content with the aim to ensure the possibility to develop financial literacy at each level of education, ensuring the availability of information, development of educational websites, as well as implementation of other educational activities important to ensure that the education level and financial literacy level could be improved.

The aim of this study is survey financial literacy level in the issues of the pension system in Latvia. Analysis was performed to investigate the self-evaluations young people of knowledge on pension system by age group, by gender and by presence of regular income from their professional activities.

To achieve the aim of the study, the ways in which young people obtain information about the pension system in Latvia, the level of young people's knowledge of the current pension system, emphasizing the investor's right to manage investments in private pension funds, as well as basic conditions to create savings at the 2 nd and 3 rd pension levels were analysed.

To conduct the research, a survey method was used, addressing youth organizations and educational institutions. The survey is designed using closed and semi-closed questions, in several questions respondents were asked to provide ratings using the Likert scale. The survey data were analysed using descriptive statistics: indicators of central tendency or location (arithmetic mean, mode, median), indicators of dispersion or variability (range, standard deviation and standard error of mean), cross-tabulations performed by age group, by gender and by presence of income from the young people professional activities - their own work. Empirical research was performed to get knowledge about young people financial literacy related to pension issues as it is important to suggest special activities if the financial literacy is low to make sure that inhabitants will be willing to contribute to their future well-being.

Financial literacy is a very deep researched aspect world-wide especially after the global financial crisis in 2009 with special attention to financial literacy of inhabitants in different parts of the globe - in Europe (Magistro 2017; Romanova \& Kudinska, 2017; Angelini, Bertoni, Stella. \& Weiss, 2019). Special attention is paid also to insurance literacy (Mare, Dragos, Dragota \& Dragos, 2019). Researchers have investigated if the financial literacy influences financial decisions and decision making, financial behaviour (Nicolini. \& Haupt, 2019) and different approaches in European countries (Nicolini, 2019) as well as level of financial education (Xiao. \& Porto, 2017; Amari, Salhi \& Jarboui, 2020).

Researchers from Estonia have conducted a study how subjective and objective knowledge of finance, behaviour in managing personal finances and socio-economic status affect financial well-being (Riitsalu \& Murakas, 2019) where one of the conclusions state that providers of finan- 
cial services should address these more in the design of their services and communication. Social marketing of financial literacy is becoming more and more important (Batraga, Praude, Salkovska. \& Afoniceva, 2018; Batraga, Salkovska, Legzdina, Rukers \& Bormane, 2018). Economic situation in country is important to organise several activities (Daugeliene, 2016; Daugeliene \& Liepinyte, 2012). Financial literacy and quality of life has a special importance facing the health problems (Pahlevan Sharif, Naghavi, Sharif Nia \& Waheed,_2020).

Researchers have discovered that there are differences in financial literacy of youth (Garg \& Singh, 2018), by gender (Okicic \& Kakes, 2019). Findings of their study has suggested that differences in financial knowledge, financial attitudes and financial behaviour between young women and men can be confirmed (Okicic \& Kakes, 2019). This aspect has to be taken into account organising marketing activities and preparing training programs to increase financial literacy of the population. Savings for future needs are investigated in the relation of financial literacy (Thomas \& Spataro, 2018). Communication aspects are considered as important for financial literacy (de Goeij, Van Campenhout \& Subotic, 2018).

Meanwhile, academics (Angrisani \& Casanova, 2019) have compared individuals' subjective and objective assessments of financial literacy and investigated whether the observed discrepancies are related to different behaviors in pension planning. Under-confident people rarely announce that they have developed a retirement plan. However, unlike overconfident people, they seem to be most eager to receive more information about pension planning. And that could mean they might be better prepared for retirement than the self-confident. The impact of perceived and actual financial literacy on financial behavior was also examined, revealing that the combined measure appears to provide a better understanding the phenomenon (Allgood, Walstad, 2016).

The study of researchers Garg and Singhh (Garg \& Singh, 2018) reveals that the financial literacy level among youth is low across the most part of the world that has become a cause of concern. Also, it has been observed that various socio-economic and demographic factors such as age, gender, income, marital status and educational attainment influence the financial literacy level of youth and there is an interrelationship between financial knowledge, financial attitude and financial behaviour (Garg \& Singh, 2018).

Researchers have found that risk and tolerance are among the important aspects in retirement savings (Tavor \& Garyn-Tal, 2016) and that financial incentives have importance for retirement savings (Jordan \& Treisch, 2010). Researchers have found that the main factors influencing financial literacy were as follows: educational level, financial attitude, financial knowledge, financial behaviour, gender, household income and investments. The consequences of financial literacy were the behaviour of incurring avoidable credit and checking fees, credit score, and the willingness to take investment risks. The authors also find some methodological, cultural, economic and theoretical moderations effects between financial literacy and antecedent/consequent constructs (Santini, Ladeira, Mette. \& Ponchio, 2019).

Models of retirement savings are issues discussed on political level and by academic researchers (Rey-Ares, Fernandez-Lopez. \& Vivel-Bua, 2018). Questions on possibility of financial literacy inclusion for requirements for residence permits are on research agenda for academic researchers (Collins. \& Yousem, 2021) and for level of financial literacy and respective financial well-being (Chavali, Mohan Raj. \& Ahmed, 2021). Researchers have investigated influence of life-style, financial literacy, demographic aspects on financial well-being (Zahra \& Anoraga, 2021). Influence of education has a big importance (Lucey \& Henning, 2021). Several other aspects has also some importance, but not so big as mentioned and analysed above. 
This study was conducted to answer the question of whether the level of financial literacy can be related to differences in gender, age group and the existence of income from their professional activities for young people in Latvia and to investigate - are there differences of knowledge on pension issues for young people if they get income from their professional activities or not to observe part of society ready to be contributors for their own as well as society well-being or they are willing to get only support from the society.

Survey of young people from Latvia on their knowledge about several financial aspects including knowledge about needs and possibilities for future pension savings was conducted in February March, 2021. The questionnaire for the survey was prepared taking into account theoretical findings in research in other countries and interest to evaluate the financial literacy of young people related to their knowledge and their views on pension savings to have inhabitants thinking about their long-term well-being in their retirement period as the current situation indicate that there is quite a big share of inhabitants in Latvia who did not pay attention to their retirement financial situation which in graet extent depend from the person's personal contribution to the social security contributions by respective persons. Main statistical indicators of respondent self-evaluations on their knowledge of pension system in Latvia in 2021 are included in Table 1.

Survey results indicate that young people in Latvia have evaluated their knowledge about the pension system in Latvia on middling level: with arithmetic mean 2.84 (in scale 1-5), most often given evaluation was 3, characterised by mode; half of respondents gave evaluation 3 or less and half of respondents gave evaluation 3 or more, characterised by median. For evaluations by respondents it was covered all evaluation scale and the indicators of variability indicate that the evaluations were quite different by young people. As it was pointed out in several theoretical findings reflected in the scientific publications that financial literacy for youngsters differ by age, by gender and by income level where for income level it is important their income from their professional activities. Distribution of evaluations on knowledge of young people about the pension system in Latvia in 2021 by gender is included in Table 2 .

Evaluations by respondents indicate that the evaluations by gender are alike but it is important to know - do those evaluations differ: are the differences statistically significant by appropriate significance level - the average evaluations of respondents was tested - do the average levels of evaluations by gender differ statistically significant. Main statistical indicators on arithmetic means of knowledge evaluations on pension system in Latvia in 2021 by gender are included in Table 3.

The arithmetic means of the evaluations of financial literacy in the pension system are higher for men, thus confirming the conclusions of previous studies on this factor. Whether thosse averages of ratings by the respondents differ statistically significant by gender has been tested by t-test. The results of testing statistical hypothesis on difference of arithmentif means of the evaluations by gender are included in Table 4 .

Data of hypotheses testing included in the pre-

\begin{tabular}{l|c|c}
\multicolumn{2}{c}{ Statistical indicators } & Values \\
\hline \multirow{2}{*}{$\begin{array}{l}\text { Valid } \\
\text { Missing }\end{array}$} & 204 \\
\hline Mean & 5 \\
\hline Standard Error of Mean & 2.84 \\
\hline Median & 0.076 \\
\hline Mode & 3 \\
\hline Standard Deviation & 3 \\
\hline Variance & 1.091 \\
\hline Range & 1.190 \\
\hline Minimum & 4 \\
\hline Maximum & 1 \\
\hline
\end{tabular}

\section{Empirical research results}

Table 1

Main statistical indicators on knowledge evaluation on pension system in Latvia in 2021

Source: Authors' calculations based on survey in 2021, $n=204$ Evaluation scale 1-5, where 1-very bad; 5-very good 
Table 2

Distribution of evaluations on knowledge evaluations on pension system in Latvia in 2021 by gender

Source: Authors' calculations based on survey in 2021, n=203; Evaluation scale 1-5, where 1-very bad; 5-very good

\section{Table 3}

Main statistical indicators on knowledge evaluation on pension system in Latvia in 2021 by gender

Source: Authors' calculations based on survey in 2021, n=203; Evaluation scale 1-5, where 1-very bad; 5-very good

\begin{tabular}{|c|c|c|c|c|c|c|c|c|}
\hline \multirow{3}{*}{ Evaluations } & \multicolumn{6}{|c|}{ Gender } & \multicolumn{2}{|c|}{ Total } \\
\hline & \multicolumn{2}{|c|}{ female } & \multicolumn{2}{|c|}{ male } & \multicolumn{2}{|c|}{ other } & \multirow{2}{*}{ number } & \multirow{2}{*}{ share $(\%)$} \\
\hline & number & share $(\%)$ & number & share (\%) & number & share (\%) & & \\
\hline 1 - very bad & 18 & 11,6 & 5 & 11,1 & 0 & 0 & 23 & 11,3 \\
\hline 2 & 43 & 27,7 & 11 & 24,5 & 2 & 66,7 & 56 & 27,6 \\
\hline 3 & 60 & 38,7 & 10 & 22,2 & 1 & 33,3 & 71 & 35,0 \\
\hline 4 & 28 & 18,1 & 10 & 22,2 & 0 & 0 & 38 & 18,7 \\
\hline 5-very good & 6 & 3,9 & 9 & 20,0 & 0 & 0 & 15 & 7,4 \\
\hline Total & 155 & 100 & 45 & 100 & 3 & 100 & 203 & 100 \\
\hline
\end{tabular}

\begin{tabular}{l|c|c|c|c|c|c|c|c|}
\hline Gender & Mean & N & $\begin{array}{c}\text { Standard } \\
\text { Deviation }\end{array}$ & $\begin{array}{c}\text { Standard Error } \\
\text { of Mean }\end{array}$ & Minimum & Maximum & Range & Median \\
\hline female & 2.75 & 155 & 1.010 & 0.081 & 1 & 5 & 4 & 3 \\
\hline male & 3.16 & 45 & 1.313 & 0.196 & 1 & 5 & 4 & 3 \\
\hline other & 2.33 & 3 & 0.577 & 0.333 & 2 & 3 & 1 & 2 \\
\hline Total & 2.83 & 203 & 1.091 & 0.077 & 1 & 5 & 4 & 3 \\
\hline 6 & 3,9 & 9 & 20,0 & 0 & 0 & 15 & 7,4 & \\
\hline 155 & 100 & 45 & 100 & 3 & 100 & 203 & 100 & \\
\hline
\end{tabular}

\section{Table 4}

Main statistical indicators of t-test on differernces of knowledge evaluation on pension system in Latvia in 2021 by gender

Source: Authors' calculations based on survey in 2021, n=203; Evaluation scale 1-5, where 1-very bad; 5-very good

\begin{tabular}{|c|c|c|c|c|c|c|c|}
\hline & \multicolumn{2}{|c|}{$\begin{array}{l}\text { Levene's Test for } \\
\text { Equality of Variances }\end{array}$} & \multicolumn{5}{|c|}{ t-test for Equality of Means } \\
\hline & $\mathrm{F}$ & Sig. & $\mathrm{t}$ & df & Sig. (2-tailed) & Mean Difference & $\begin{array}{l}\text { Standard Error } \\
\text { Difference }\end{array}$ \\
\hline $\begin{array}{l}\text { Equal variances } \\
\text { assumed }\end{array}$ & 8.076 & 0.005 & -2.216 & 198 & 0.028 & -0.407 & 0.184 \\
\hline $\begin{array}{l}\text { Equal variances } \\
\text { not assumed }\end{array}$ & & & -1.921 & 59.908 & 0.059 & -0.407 & 0.212 \\
\hline
\end{tabular}

vious table indicate that there are no statistically signifficant differences in self-evaluations on pension system knowledge by gender. The other aspect covered in scientific publications that resprsentatives from different age groups have different level of financial literacy. Our investigations on knowledge about the pension system in Latvia by age groups were examinded in the next part of our empiricalresearch. Distribution of evaluations by young persons on pension system in Latvia in 2021 by age group is included in Table 5 .

Evaluations by respondents indicate that the evaluations by age group are alike but it is important to know - do those evaluations differ statistically significant with certain significance level. Main statistical indicators on knowledge evaluations by young persons on pension system in Latvia in 2021 by age group are included in Table 6 . 


\begin{tabular}{|l|c|c|c|c|c|}
\hline \multicolumn{1}{|c|}{ Evaluations } & \multicolumn{5}{|c|}{ Age group } \\
\hline 1 very bad & $18-20$ & $21-23$ & $24-25$ & $26-30$ & Total \\
\hline 2 & 9 & 7 & 3 & 4 & 23 \\
\hline 3 & 29 & 12 & 4 & 11 & 56 \\
\hline 4 & 20 & 31 & 9 & 11 & 71 \\
\hline 5 -very good & 12 & 10 & 6 & 11 & 39 \\
\hline Total & 3 & 7 & 1 & 4 & 15 \\
\hline
\end{tabular}

Table 5

Distribution of evaluations on knowledge evaluation on pension system in Latvia in 2021 by age group

Source: Authors' calculations based on survey in 2021, $n=204$; Evaluation scale 1-5, where 1-very bad; 5-very good

Table 6

\begin{tabular}{|c|c|c|c|c|c|c|c|c|}
\hline Age group & Mean & $\mathrm{N}$ & Standard Deviation & Standard Error of Mean & Minimum & Maximum & Range & Median \\
\hline $18-20$ & 2.60 & 73 & 1.037 & 0.121 & 1 & 5 & 4 & 2 \\
\hline $21-23$ & 2.97 & 67 & 1.087 & 0.133 & 1 & 5 & 4 & 3 \\
\hline $24-25$ & 2.91 & 23 & 1.083 & 0.226 & 1 & 5 & 4 & 3 \\
\hline $26-30$ & 3.00 & 41 & 1.162 & 0.181 & 1 & 5 & 4 & 3 \\
\hline Total & 2.84 & 204 & 1.091 & 0.076 & 1 & 5 & 4 & 3 \\
\hline
\end{tabular}

The arithmetic means of the assessments gradually increase with increasing the age group, which is not surprising, however, in this sample group the age group 21-23 has a slightly higher arithmetic mean ogf the evaluations than for the group aged 24-25. Whether these estimates differ statistically signifficant depending on the age group, we have tested it by the analysis of variance - ANOVA where there are compared arithmetic means of the evaluations and tested do they differ statistically significant. The results of testing statistical hypothesis on difference of average evaluations on youngsters knowledge about pension system in Latvia by the age group are included in Table 7.

\begin{tabular}{l|c|c|c|c|c|}
\hline & Sum of Squares & $\mathrm{df}$ & Mean Square & F & Sig. \\
\hline Between Groups & 6.416 & 3 & 2.139 & 1.818 & 0.145 \\
\hline Within Groups & 235.246 & 200 & 1.176 & \\
\hline Total & $\mathbf{2 4 1 . 6 6 2}$ & $\mathbf{2 0 3}$ & & \\
\hline
\end{tabular}

Analysis of variance (ANOVA) results indicate that the average evaluations by age groups do not differ statistically significant by significance level less than 0.145 . Main statistical indicators of correlation analysis on young people knowledge evaluations on pension system in Latvia, age group and gender in 2021 investigating the relation of those analysed aspects mentioned before are reflected in Table 8.
Main statistical indicators on pension system in Latvia in 2021 by age group

Source: Authors' calculations based on survey in 2021, n=204; Evaluation scale 1-5, where 1-very bad; 5-very good

Table 7

Main statistical indicators of analysis of variance (ANOVA) on knowledge evaluation on pension system in Latvia in 2021 by age group

Source: Authors' calculations based on survey in 2021, Evaluation scale 1-5, where 1-very bad; 5-very good on knowledge evaluation 
Table 8

Main statistical indicators of correlation analysis on knowledge evaluations on pension system in Latvia, age group and gender in 2021

Source: Authors' calculations based on survey in 2021

\section{Table 9}

Crosstabulation on knowledge evaluation on pension system in Latvia by age group and by regular income from professional activities

Source: Authors' calculations based on survey in 2021, Evaluation scale 1-5, where 1-very bad; 5-very good

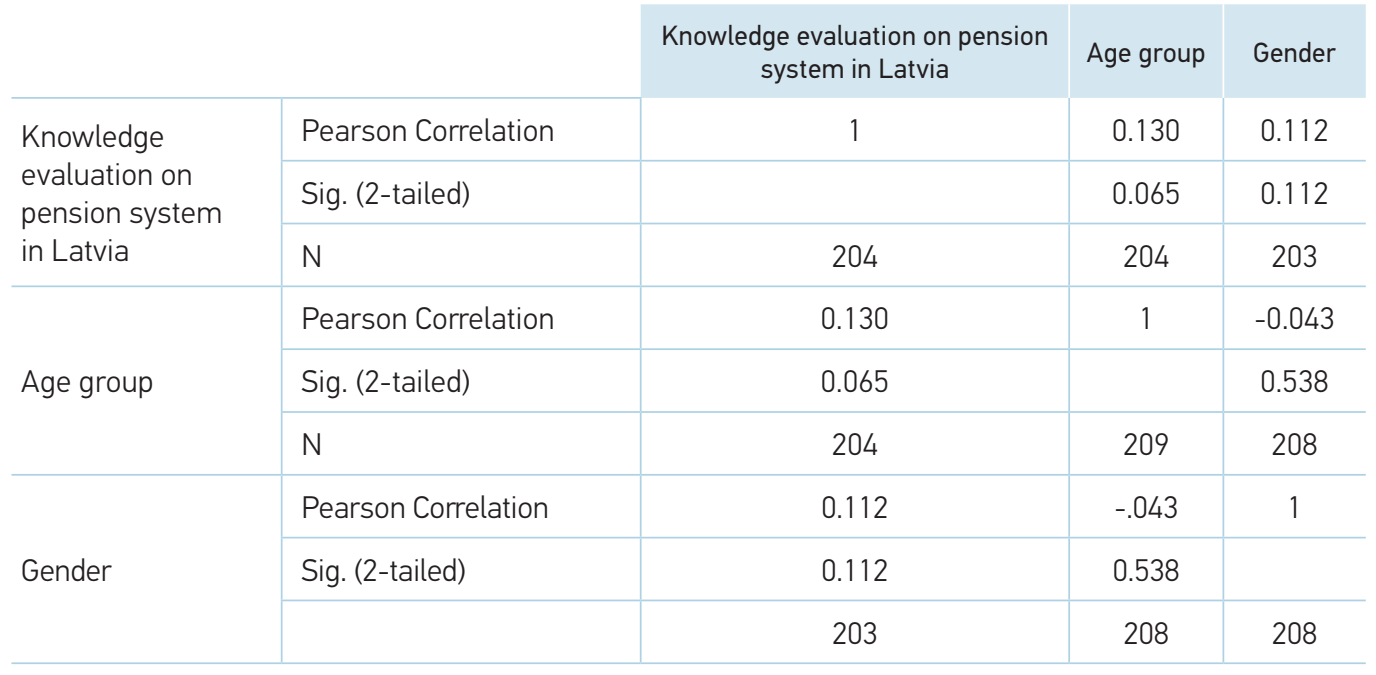

Correlation analysis results indicate that the knowledge level evaluations of young people in Latvia on pension system has close correlation with age groups where the correlation coefficient is statistically significant with significance level less than 0.065 and is not statistically significant with gender. The other aspect indicated in scientific publications was that there are different financial literacy levels of young people depending from the income level. This aspect was analysed also in our empirical research where the main results are included in Table 9.

\begin{tabular}{|c|c|c|c|c|c|c|}
\hline \multirow{2}{*}{\multicolumn{2}{|c|}{$\begin{array}{c}\text { Evaluations by regular income from } \\
\text { professional activities }\end{array}$}} & \multicolumn{4}{|c|}{ Age group } & \multirow{3}{*}{$\begin{array}{c}\text { Total } \\
8\end{array}$} \\
\hline & & \multirow{2}{*}{$\begin{array}{c}18-20 \\
2\end{array}$} & \multirow{2}{*}{$\begin{array}{c}21-23 \\
4\end{array}$} & \multirow{2}{*}{$\begin{array}{c}24-25 \\
0\end{array}$} & \multirow{2}{*}{$\begin{array}{c}26-30 \\
2\end{array}$} & \\
\hline \multirow{6}{*}{ Yes } & 1-very bad & & & & & \\
\hline & 2 & 11 & 3 & 2 & 3 & 19 \\
\hline & 3 & 11 & 16 & 6 & 5 & 38 \\
\hline & 4 & 7 & 7 & 4 & 11 & 29 \\
\hline & 5-very good & 3 & 5 & 1 & 4 & 13 \\
\hline & Total & 34 & 35 & 13 & 25 & 107 \\
\hline \multirow{6}{*}{ No } & 1-very bad & 7 & 3 & 3 & 2 & 15 \\
\hline & 2 & 18 & 9 & 2 & 8 & 37 \\
\hline & 3 & 9 & 15 & 3 & 6 & 33 \\
\hline & 4 & 5 & 3 & 2 & 0 & 10 \\
\hline & 5-very good & 0 & 2 & 0 & 0 & 2 \\
\hline & Total & 39 & 32 & 10 & 16 & 97 \\
\hline
\end{tabular}

Results of analysis show that the evaluations of young people having or not having income from their professional activities are different. How different are those results in relation of presence or absence of income on the professional activities are investigated by symmetric measures - main results of this analysis are included in Table 10. 


\begin{tabular}{|c|c|c|c|c|c|c|}
\hline & \multicolumn{2}{|c|}{ Regular income from professional activities } & Value & Asymp. Std. Error ${ }^{a}$ & Approx. $\mathrm{T}^{\mathrm{b}}$ & Approx. Sig. \\
\hline \multirow{3}{*}{ Yes } & $\begin{array}{l}\text { Interval by } \\
\text { Interval }\end{array}$ & Pearson's R & 0,184 & 0,097 & 1,918 & $0,058^{c}$ \\
\hline & Ordinal by Ordinal & Spearman Correlation & 0,207 & 0,096 & 2,164 & $0,033^{c}$ \\
\hline & \multicolumn{2}{|l|}{$\mathrm{N}$ of Valid Cases } & 107 & & & \\
\hline \multirow{3}{*}{ No } & $\begin{array}{l}\text { Interval by } \\
\text { Interval }\end{array}$ & Pearson's R & $-0,014$ & 0,089 & $-0,135$ & $0,893^{\mathrm{C}}$ \\
\hline & Ordinal by Ordinal & Spearman Correlation & 0,044 & 0,100 & 0,432 & $0,667^{c}$ \\
\hline & \multicolumn{2}{|l|}{$\mathrm{N}$ of Valid Cases } & 97 & & & \\
\hline
\end{tabular}

Table 10

Symmetric measures on crosstabulation on knowledge evaluation on pension system in Latvia by age group and by regular income from professional activities

Source: Authors calculations based on survey in 2021 Evaluation scale 1-5, where 1-very bad; 5-very good

a. Not assuming the null hypothesis.

b. Using the asymptotic standard error assuming the null hypothesis.

c. Based on normal approximation.

The results of analusis indicate that the evaluations of financial literacy increase if person is older and if the person has income from the professional activities and has quite different situation if there are no income from young personds professional activities. The results of this analysis confirm that there are necessary activities from different institutions to increase the financial literacy level of young people and to make educational and moral support for their professional activities.

» Financial literacy and saving models are on investigation of many academic researchers with special attention to retirement savings.

"Persons by different gender and different age groups as well as different income levels from the person's professional activities have different motivations for retirement savings for voluntary pension models.

" Young people knowledge and motivations for voluntary pension savings differ by age groups - older groups of young people are better informed about pension system, but the correlation is not statistically significant with significance level less than 0.065 .

» Young persons who have income from their professional activities by increasing their age have higher financial literacy level.

The paper is supported by the National Research Programme INTERFRAME-LV.

Amari, M., Salhi, B. \& Jarboui, A. (2020). Evaluating the effects of sociodemographic characteristics and financial education on saving behavior. International Journal of Sociology and Social Policy, 40(11/12), 14231438.https://doi.org/10.1108/IJSSP-03-2020-0048

Angelini, V., Bertoni, M., Stella, L. \& Weiss, C.T. (2019). The ant or the grasshopper? The long-term consequences of Unilateral Divorce Laws on savings of European households. European Economic Review, 119, 97-113. https://doi.org/10.1016/j.euroecorev.2019.07.002
Angrisani, M. \& Casanova, M. (2019). What you think you know can hurt you: Under/over confidence in financial knowledge and preparedness for retirement. Journal of Pension Economics and Finance, 1-16. https://doi.org/10.1017/S1474747219000131

Allgood, S. \& Walstad, W, B. (2016) The effects of perceived and actual financial literacy on financial behaviors. Economic Inquiry, 54, 675-697. https://doi. org/10.1111/ecin.12255

Batraga, A., Praude, V., Salkovska, J. \& Afoniceva, 0. (2018) - a. The Influence of Sales Stimulation Methods

\section{Conclusions}

References 
on the Behaviour of Consumers While Making the Decision on Purchase of Products in the Latvian Market Consumer Behavior, organisational Strategy and Financial Economics. Eurasian Studies in Business and Economics, 9, 3-23. https://doi.org/10.1007/9783-319-76288-3_1

Batraga, A., Salkovska, J., Legzdina, A., Rukers, I. \& Bormane, S. (2018) - b. Consumer Behavior Affecting Factors Leading to Increased Competitiveness during Holiday Season. Economic Science for Rural Development, 48, 329-337. https://doi.org/10.22616/ ESRD.2018.102

Chavali, K., Mohan Raj, P. \& Ahmed, R. (2021). Does Financial Behavior Influence Financial Well-being? Ournal of Asian Finance Economics and Business, 8(2), 273-280.

Collins, J. \& Yousem, D. (2021). Financial Literacy: Should It Be a Required Part of the Residency Curriculum? Academic Radiology, 28(4), 589-590. https://doi. org/10.1016/j.acra.2020.12.014

Daugeliene, R. (2016). EU's Political Actions for the Enhancement of Macroeconomic Stability in Confrontation with Great Economic Recession. Entrepreneurship, Business and Economics, 2(3-2), 647-663. https://doi.org/10.1007/978-3-319-27573-4_42

Daugeliene, R. \& Liepinyte, M. (2012). Interrelation of Misleading Advertising and Solutions of Consumers: Legal Regulation and Institutional Background in Lithuania. European Integration Studies, 6, 192-201. https://doi.org/10.5755/j01.eis.0.6.1584

Garg, N. \& Singh, S. (2018). Financial literacy among youth. International Journal of Social Economics, 45(1), 173-186. https://doi.org/10.1108/IJSE-112016-0303

de Goeij, P., Van Campenhout, G. \& Subotic, M. (2018). Improving Index Mutual Fund Risk Perception: Increase Financial Literacy or Communicate Better? Economic Notes, 47(2-3), 519-551. https://doi. org/10.1111/ecno.12112

Jordan, S. \& Treisch, C. (2010). The perception of tax concessions in retirement savings decisions. Qualitative Research in Financial Markets, 2(3), 57-184. https://doi.org/10.1108/17554171011091737

Kotecha, M., Kinsella, R. \& Arthur, S. (2010) Research on Predictions of Income in Retirement, Working Paper No. 87, Leeds: Stationery Office, Department of Work and Pensions

Lucey, T.A. \& Henning, M.B. (2021). Toward critically compassionate financial literacy: How elementary preservice teachers view the standards. Theory and Research in Social Education, 49(1), 107-136. https:// doi.org/10.1080/00933104.2020.1859422
Magistro, B (2017). Financial literacy and support for free trade in the UK. World Economy, 43(8), 20502069. https://doi.org/10.1111/twec.12951

Mare, C., Dragos, S.L., Dragota, I.-M. \& Dragos, C.M. (2019). Insurance Literacy and Spatial Diffusion in the Life Insurance Market: A Subnational Approach in Romania. Eastern European Economics, 57(5), 375-396 https://doi.org/10.1080/00128775.2019.1618194

Nicolini, G. (2019). Financial Literacy in Europe Assessment Methodologies and Evidence from European Countries. Book Series: Routledge International Studies in Money and Banking, Volume: 100, 269 p. https://doi.org/10.4324/9780429431968

Nicolini, G. \& Haupt, M. (2019). The Assessment of Financial Literacy: New Evidence from Europe. International Journal of Financial Studies, 7(3), article number 54, DOI: 10.3390/ijfs7030054 https://doi. org/10.3390/ijfs 7030054

Okicic, J. \& Kakes, D. (2019). Insights into Gender Differences in Financial Literacy of Youth. In M.L. Simic \& Crnkovic, B. (ED). 8th International Scientific Symphosium Economy of Eastern Croatia - Vision and Growth. Book Series: Medunarodni Znanstveni Simpozij Gospodarstvo Istocne Hrvatske-Jucer Danas Sutra (pp. 474-484).

Pahlevan Sharif, S., Naghavi, N., Sharif Nia, H. \& Waheed, H. (2020). Financial literacy and quality of life of consumers faced with cancer: a moderated mediation approach. International Journal of Bank Marketing, 38(5), 1009-1031. https://doi.org/10.1108/IJBM10-2019-0355

Rey-Ares, L., Fernandez-Lopez, S. \& Vivel-Bua, M. (2018). The Influence of Social Models on Retirement Savings: Evidence for European Countries. Social Indicators Research, 136(1), 247-268. https://doi. org/10.1007/s11205-016-1533-9

Riitsalu, L. \& Murakas, R. (2019). Subjective financial knowledge, prudent behaviour and income - the predictors of financial well-being in Estonia. International Journal of Bank Marketing, 37(4), 934-950. https:// doi.org/10.1108/IJBM-03-2018-0071

Romanova, I. \& Kudinska, M. (2017). Banking and Fintech: a Challenge or Opportunity? In. S. Grimma, S. Bezzina, I. Romanova \& R. Rupeika-Apoga (Ed.), Contemporary Issues in Finance: Current Challenges from Across Europe, Book Series: Contemporary Studies in Economic and Financial Analysis, Volume: 98 (pp. 21-35). https://doi.org/10.1108/S1569375920160000098002

Santini, F.D.O., Ladeira, W.J., Mette, F.M.B. \& Ponchio, M.C. (2019). The antecedents and consequences of financial literacy: a meta-analysis. International Jour- 
nal of Bank Marketing, 37(6), 1462-1479. https://doi. org/10.1108/IJBM-10-2018-0281

Strauss, K. (2008). Re-engaging with rationality in economic geography: behavioural approaches and the importance of context in decision-making. Journal of Economic Geography, 8(2), 137-156. https:// doi.org/10.1093/jeg/lbm048

Tavor, T. \& Garyn-Tal, S. (2016). Risk tolerance and rationality in the case of retirement savings. Studies in Economics and Finance, 33(4), 688-703. https://doi. org/10.1108/SEF-10-2015-0240

\section{DUNDURE EVIJA}

\section{Master of Business Administration, Doctoral student}

University of Latvia

\section{Fields of interests}

Voluntary savings role in pension system adequacy.

\section{Address}

Aspazijas bulv. 5, Riga, Latvia, LV - 1050,

+37129493458

Dundure.Evija@gmail.com
Thomas, A. \& Spataro, L. (2018). Financial Literacy, Human Capital and Stock Market Participation in Europe. Journal of Family and Economic Issues, 19(4), 532-550. https://doi.org/10.1007/s10834018-9576-5

Xiao, J.J. \& Porto, N. (2017). Financial education and financial satisfaction: Financial literacy, behavior, and capability as mediators. International Journal of Bank Marketing, 35(5), 805-817. https://doi.org/10.1108/ IJBM-01-2016-0009

Vicente, M.R. \& Lopez, A.J. (2017).

\section{SLOKA BIRUTA}

About the

Dr.oec. Professor authors
University of Latvia

\section{Fields of interests}

Multivariate data analysis, social marketing, quantitative analysis.

\section{Address}

Aspazijas bulv. 5, Riga, LV - 1050,

$+37129244966$

Biruta.Sloka@lu.lv 